\title{
PERSAUDARAAN LINTAS IMAN: Relasi Legitimasi dan Identitas Elit Agama Kota Palangka Raya
}

\author{
Interfaith Brotherhood: Relation Legitimacy \\ And Elite Identities of Religions in Palangkaraya City
}

\author{
Sarmauli \\ STAKN Palangka Raya \\ Tampung Penyang, RT A, Milono km.6 Palangka Raya \\ Email: uli_rahul2002@yahoo.com
}

Naskah diterima tanggal 6 Maret 2015. Naskah direvisi tanggal 2 April 2015. Naskah disetujui tanggal 22 Mei 2015

\begin{abstract}
Abstrak
Penelitian ini merupakan upaya memahami proses interaksionisme simbolik legitimasi elit enam agama dalam mengkonstruksi persaudaraan lintas iman di Kota Palangka Raya dan menemukan model interaksionisme simbolik relasi legitimasi dan identitas elit enam agama dalam mengkonstruksi persaudaraan lintas iman di kota Palangka Raya. Metode penelitian penelitian kualitatif. Penelitian ini menggunakan dua strategi penelitian yang didasarkan atas: (1) karakteristik pertanyaan penelitian, (2) ketegasan dan keakuratan dalam analisis, (3) perspektif yang khusus dan unik untuk menghasilkan realitas yang menyeluruh. Hasil dari penelitian ini menggali pemaknaan kembali interaksi legitimasi dan identitas dalam mewujudkan persaudaraan lintas iman. Hal tersebut dilakukan untuk membuktikan asumsi bahwa persaudaraan lintas iman merupakan strategi menciptakan perdamaian yang dijalankan tanpa konfrontatif, kerukunan yang dibangun secara bijak serta nilai bersama yang bisa diteladani.
\end{abstract}

Kata kunci: interaksi, elit agama, persaudaraan

\begin{abstract}
The aims of research are the attempts to understand the process of symbolic interaction of elite legitimacy of six religions in constructing brotherhood in interfaith in Palangkaraya city and to find out the model of symbolic interaction of relation legitimacy and elite identities of six religions in constructing brotherhood in interfaith in Palangkaraya city. The method of research was the qualitative study. The research employed two strategies based on: (1) the characteristics of the research questions, (2) the specificity and the accuracy in the analysis, (3) particular and unique perspective to result a comprehensive reality. The results of the research explore the back meaning of legitimacy interaction and identity in creating brotherhood in interfaith. The research was conducted to prove the assumption that the interfaith brotherhood is a strategy in making peace carried out without confrontation; harmony was built wisely and shared values that can be imitated.
\end{abstract}

Keywords: interaction, elite religious, brotherhood

\section{PENDAHULUAN}

$\mathrm{P}$ erdamaian merupakan ajaran yang singgah di berbagai kitab suci yang dibagikan kepada seluruh umat manusia. Sayangnya gesekan dan konflik beragama menghambat proses penciptaan perdamaian di antara umat beragama.
Gesekan maupun konflik beragama menjadi salah satu fenomena natural dan selalu menjadi bagian dari realitas kemanusiaan (Abu Nimer, 2000: 224). Persoalan gesekan maupun konflik antar umat beragama terjadi manakala pemahaman inklusif sebagai kesadaran kolektif tidak dijalankan secara holistik. Akibatnya, persoalan relasi antar 
umat beragama sering menemui jalan buntu dan mengendap menjadi tidak terselesaikan. Situasi tersebut menimbulkan polemik dan kekaburan dalam perumusan keberagamaan yang inklusif pada tataran implementasi.

Kondusifitas keberagamaan dipengaruhi oleh pemahaman umat beragama dan situasi sosio-kultural. Eldering menyebut keberagamaan dalam struktur sosial akan kondusif manakala terkonstruksi dalam dua elemen: pertama, perhatian serius terhadap eksistensi perbedaan ras, sejarah, status sosial, dan budaya masyarakat. Keadaan ini terbentuk karena adanya ekspansi ekonomi maupun arus mobilitas sosial. Kedua, perhatian terhadap ideologi yang membentuk identitas masyarakat dan interaksi di antara kelompok sosial masyarakat (Eldering, 1996: 316).

Kota Palangka Raya memiliki modal kultural dan sosial yang cukup besar dalam membangun perdamaian dalam keharmonisan antar umat beragama. Peran-peran elit agama maupun lembaga sosial keagamaan setempat seperti NU, Muhammadiyah, PGI dan sebagainya memiliki andil besar dalam membangun interaksi dan komunikasi antar umat beragama. Ini nampak sebagaimana terlihat dari frekuensi dialog lintas agama yang digelar secara rutin. Misalnya, dialog lintas iman untuk persaudaraan yang digelar Institut Pendidikan Theologia Balewiyata Malang pada 30 Mei 3013 lalu, melibatkan NU dan Muhammadiyah secara berkala mempromosikan perdamaian dan golek sedulur (mencari saudara) lintas iman. Hal tersebut merupakan bentuk intervensi kedamaian melalui persaudaraan lintas iman. Menurut Abu Nimer, memfasilitasi saluran interaksi dan komunikasi antar umat beragama dinilai lebih produktif dalam menurunkan ketegangan dan membangun kembali relasi kedamaian di antara umat beragama. Interaksi berperan besar dalam menyatukan dan melibatkan seluruh umat beragama dalam mengkonstruksi kedamaian dalam keberagamaan (Abu Nimer, 2000: 246).

Ironisnya, ada kekhawatiran yang selalu mengemuka, apakah relasi keberagamaan yang saat ini terjadi di kota Palangka Raya dalam keadaan semu? Dialog Forum Komunikasi Umat Beragama Kota Palangka Raya dengan Rektor STAIN Palangka Raya pada 7 Juni 2013 lalu, mengafirmasi adanya potensi konflik keberagamaan yang laten terutama menyangkut relasi umat beragama. PMB No. 8 dan 9 tahun 2006, Pergub No. 1 tahun 2007 dan Perwal No. 8 tahun 2007 merupakan sederet regulasi yang menyulut polemik relasi antar umat beragama. Hasil dialog menyebutkan pemahaman sepatah terhadap peraturan tersebut kerap menimbulkan keresahan. Hal ini dipengaruhi oleh legitimasi iman yang berbeda dan belum ditemukan persamaan persepsi antar agama dalam menyikapi peraturan tersebut. Dalam tataran inilah, dibutuhkan adanya model relasi keberagamaan yang diasumsikan memiliki kekuatan peyangga sekaligus peletak dasar konsensus persaudaraan lintas iman di kota Palangka Raya. Maka, salah satu asumsi model yang ditawarkan dalam menghadapi problem keberagamaan ini, sebagai berikut:

Gambar 1.1: Model Persaudaraan Lintas Iman



Model sebagaimana tersaji pada gambar 1.1, menjelaskan persaudaraan lintas iman sebagai hasil dari interaksi keberagamaan yang bersumber dari legitimasi dan identitas yang dimiliki elit agama. Disebabkan berasal dari logika internal elit agama, diharapkan proses relasi legitimasi dan identitas menghasilkan pemaknaan kembali golek sedulur (mencari saudara) lintas iman yang berbasis kepada spiritualitas tanpa kekerasan, keteduhan dalam beribadah dan kepekaan terhadap realitas. Berangkat dari hal tersebut, penelitian ini mencoba mencari format persaudaraan lintas iman yang universal dan lebih sistematis berbasis kepada nilainilai perdamaian yang singgah di berbagai kitab suci. 
Penelitian ini memiliki dua tujuan: Pertama, sebagai upaya memahami proses interaksionisme simbolik legitimasi elit enam agama dalam mengkonstruksi persaudaraan lintas iman di kota Palangka Raya. Kedua, menemukan model interaksionisme simbolik relasi legitimasi dan identitas elit enam agama dalam mengkonstruksi persaudaraan lintas iman di kota Palangka Raya.

Secara praktis, penelitian ini diharapkan mampu berkontribusi kepada pengambil kebijakan untuk mengembangkan program keberagamaan yang lebih inklusif melalui persaudaraan lintas iman di antara umat beragama. Penelitian ini juga diupayakan membawa dampak munculnya sikap simpati di antara elit agama agar melahirkan persaudaraan lintas iman sebagai nilai global (global values), sehingga di antara pemeluk berupaya menjaga pilar perdamaian di internal maupun eksternal umat beragama.

\section{Tinjauan Pustaka}

Legitimasi memiliki peran kuat dalam menciptakan kekuasaan dan otoritas. Legitimasi merupakan representasi atas hak untuk memerintah
(Coleman, 2007: 23). Weber sebagaimana dikutip Tyler, menyatakan terdapat tiga jenis legitimasi, yaitu; pertama, legitimasi berdasar penghormatan terhadap kebiasaan dan nilai-nilai tradisi (traditional authority). Kedua, legitimasi berdasar aksi atau karakter elit agama (charismatic authority). Ketiga, legitimasi berdasar proses peraturan dan intepretasinya (rational bureaucratic authority) (Tyler, 2006: 378). Dalam konteks keberagamaan, apakah benar tiga hal tersebut mampu menjadi faktor dominan dalam memberikan legitimasi atas eksistensi persaudaraan lintas iman? Kajian Weber dan Coleman, belum memberikan konsep operasional yang jelas manakala terjadi benturan antara legitimasi tradisi, elit agama, dan peraturan yang berlaku. Penelitian ini akan menguji apakah ada benturan legitimasi yang dialami elit agama dalam mengkonstruksi persaudaraan lintas iman di kota Palangka Raya.

Adaptasi, dialektika pengalaman dan partisipasi menjadi landasan operasional legitimasi. Dalam pandangan Beetham, tiga hal tersebut menjadi pangkal legitimasi operasionalnya dalam ruang sosial, sebagaimana tergambar dalam tabel berikut:

Tabel 1.2: Kerangka Operasional Legitimasi

\begin{tabular}{ccc}
\hline Kriteria legitimasi & Level operasional & Bentuk tidak terlegitimasi \\
\hline Penyesuaian dengan peraturan & Peraturan-peraturan & Illegitimacy: Ketidaktertiban peraturan \\
Berbagi pengalaman kepercayaan & Justifikasi pengalaman & Deficit kepercayaan: hilangnya berbagi \\
(sharing beliefs) & kepercayaan & nilai-nilai dalam kepercayaan \\
Pernyataan persetujuan & Aksi & Delegitimasi: penentangan masyarakat \\
\hline Sumber:(Beytham $, 1991: 20)$ &
\end{tabular}

Berdasarkan tabel 1.2 di atas, legitimasi memainkan peran penting sebagai peyangga keberagamaan manakala: pertama, mampu menyesuaikan diri dengan peraturan yang berlaku secara umum. Kedua, didasarkan kepada sistem keimanan masing-masing pemeluk. Ketiga, keterlibatan aktif masing-masing pemeluk dalam berbagai kegiatan keberagamaan antar umat yang disepakati bersama (Beetham, 1991: 1718). Legitimasi memiliki fungsi untuk membuat perwujudan keberagamaan yang inklusif menjadi lebih mudah dan efektif disebabkan adanya: (1) sistem motivasi internal dari pemeluk agama, (2) memiliki rasa kewajiban dan tanggung jawab dan (3) memiliki panduan perilaku (guide their behavior) untuk mewujudkan hal tersebut (Tyler, 2006: 377). Namun sayangnya, kajian yang diberikan Tyler tidak menjelaskan situasi dan kondisi seperti apa legitimasi dalam konteks persaudaraan lintas iman dapat berjalan efektif? Penelitian ini juga ingin memahami dalam situasi seperti apa legitimasi dalam persaudaraan lintas iman dapat berjalan efektif.

Legitimasi elit agama memperjelas posisi pemeluk masing-masing agama dalam membangun relasi antar umat beragama (Rehfeld, 2005: 18) Legitimasi keberagamaan juga menpunyai signifikansi dalam mempengaruhi artikulasi kekuatan dan otoritas elit agama. Identifikasi legitimasi antar elit agama merupakan langkah etika universal dalam mempertemukan logika internal masing-masing agama (Nasar Meer, 2010: 37). Dalam penelitian ini, ingin mencari relevansi identifikasi legitimasi sebagai dasar pembentukan logika internal masing-masing agama sebagaimana diurai Nasar Meer di atas.

Sementara identitas merupakan pikiran mendasar yang berkaitan dengan pembentukan perilaku keberagamaan (Simon, 2004: 1). Identitas membentuk gambaran sosok individu yang terikat 
dengan dirinya (self), afiliasi keberagamaan, serta posisi dan peran dalam status sosial yang diemban. Identitas dihasilkan dari persepsi subjektif internal, refleksi diri dan karakteristik eksternal yang dilakukan individu (Peek, 2005: 216). Dengan kata lain, setiap pemikiran seseorang terpengaruh atas identitas yang disandangnya. Simon menegaskan manusia menuju bangunan yang berbeda yang disebut gereja, sinagoge, atau masjid dikarenakan masing-masing memiliki identitas religius yang berbeda sebagai pemeluk kristen, yahudi ataupun muslim (Simon, 2004: 1). Dalam penelitian ini. keakurasian kajian Simon terhadap konsepsi identitas keberagamaan akan diuji dan diterapkan dalam konteks konstruksi persaudaraan lintas iman. Interaksi antar umat beragama secara kontinyu memiliki kontribusi terhadap individu dalam menciptakan kembali pemaknaan (recreated) identitasnya. Persaudaraan lintas iman akan terbangun dan menghasilkan titik pertemuan makna yang sama (common values) ketika terjalin proses koordinasi, kooperatif dan aksi kemanusiaan antar elit agama (Simon, 2004: 21). Meminjam konsep Moore dan Woodrow, interaksi identitas elit agama memiliki kepentingan untuk mendapatkan pertukaran informasi dari perasaan, persepsi, perhatian, kepentingan, kebutuhan, tujuan, visi maupun langkah pilihan yang diambil masingmasing pemuka agama dalam menciptakan persaudaraan lintas iman (Moore dan Woodrow, 2010: 33). Pada akhirnya, penelitian ini ingin menggali pemaknaan kembali interaksi legitimasi dan identitas dalam mewujudkan persaudaraan lintas iman. Hal tersebut dilakukan untuk membuktikan asumsi bahwa persaudaraan lintas iman merupakan strategi menciptakan perdamaian yang dijalankan tanpa konfrontatif, kerukunan yang dibangun secara bijak serta nilai bersama yang bisa diteladani.

Penelitian ini berusaha memahami persaudaraan lintas iman dalam setting perkotaan yang memiliki kekayaan modal kultural dan sosial. Kolaborasi teori legitimasi dan identitas membentuk model keberagamaan yang unik yang bersumber dari sistem motivasi keberagamaan, rasa kewajiban dan tanggung jawab, kaya panduan perilaku (guide their behavior), konsepsi diri, afiliasi keberagamaan, serta posisi dan peran pemeluk agama dalam berbagai status. Oleh karena itu, penelitian ini menguatkan legitimasi dan konsepsi identitas elit enam agama sebagai struktur makro yang melingkupi persaudaraan lintas iman.
Persaudaraan lintas iman terpilah menjadi tiga domain. Domain pertama adalah pengalaman legitimasi elit enam agama yang meliputi: pertama, pemosisian legitimasi dan motivasi keberagamaan yang inheren dalam peraturan yang berlaku. Kedua, pengalaman keimanan masing-masing elit enam agama. Ketiga, keterlibatan aktif elit enam agama dalam memainkan kekuatan dan otoritas dalam berbagai kegiatan keberagamaan antar umat. Di sisi lain, domain identitas elit enam agama yang meliputi konsepsi diri dan afiliasi keberagamaan, berdampak kepada konfirmasi motivasi, perilaku, peran dan statusnya dalam mewujudkan persaudaraan lintas iman.

Mengacu kepada pemikiran di atas, penelitian ini mengambil posisi untuk memahami relasi legitimasi dan identitas dalam mewujudkan persaudaraan lintas iman. Titik perhatian dari relasi legitimasi dan identitas tersebut terletak pada makna-makna persaudaraan lintas iman berdasarkan pandangan, kepercayaan, nilai, definisi, dalil atau teori sehari-hari yang ada di kalangan elit enam agama. Pengalaman elit enam agama dalam menjalani proses persaudaraan lintas iman dilingkupi oleh seperangkat nilai-nilai yang menjadi pertimbangan elit enam agama dalam bertindak dan bersikap. Dengan demikian, kerangka pikir penelitian ini adalah sebagai berikut:

Gambar 1.2. Kerangka Pikir

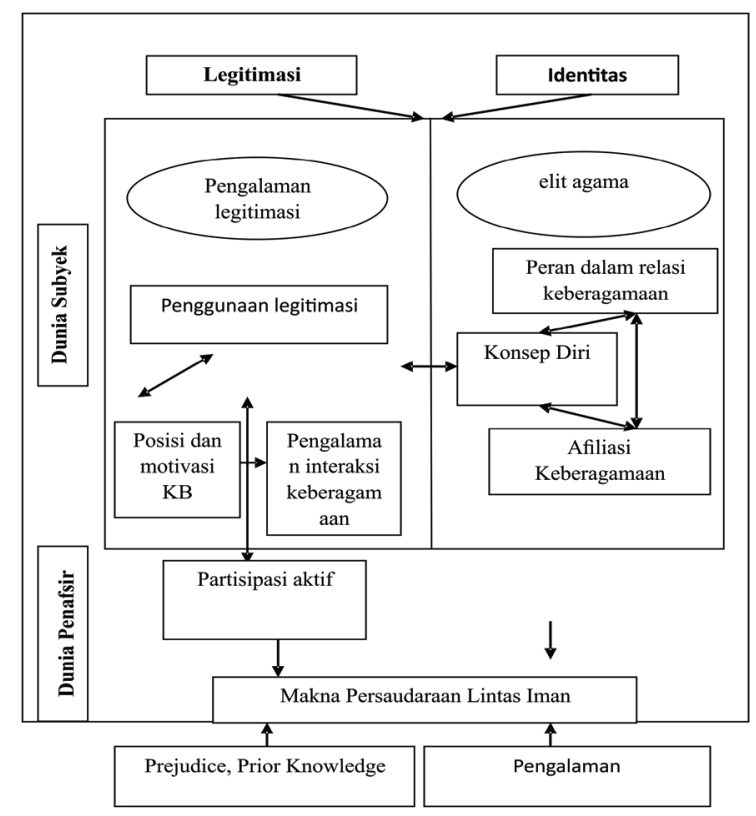

Sumber: Intisari dari Moore \& Woodrow. 2010, Lori. 2005. Rehfeld, 2005. Bernd. 2004. Tyler, 2006. 
Penjelasan konsep dari gambar 1.2 di atas adalah sebagai berikut: Persaudaraan lintas iman dalam penelitian ini merujuk pada dua makna. Pertama, persaudaraan lintas iman sebagai pengalaman teologis dalam wujud operasionalisasi legitimasi. Kedua persaudaraan lintas iman sebagai upaya elit enam agama untuk mangatur fungsi dan perannya dalam mewujudkan persaudaraan lintas iman dengan mendayagunakan identitas yang melekat seperti konsepsi diri, afiliasi keberagamaan, motivasi, perilaku, peran dan statusnya. Penentuan subyek penelitian dibatasi hanya bagi elit agama dari enam agama. Sementara makna persaudaraan lintas iman dalam penelitian ini berasal dari penyimakan interpretasi dan tindakan elit enam agama. Makna di sini merujuk pada makna konstruksional hasil interpretasi subyek dan peneliti terhadap persaudaraan lintas iman

\section{METODE PENELITIAN}

Jenis penelitian ini adalah penelitian kualitatif. Penelitian ini menggunakan dua strategi penelitian yang didasarkan atas: (1) karakteristik pertanyaan penelitian, (2) ketegasan dan keakuratan dalam analisis, (3) perspektif yang khusus dan unik untuk menghasilkan realitas yang menyeluruh (Denzin dan Lincoln, 2009: 281). Dua strategi tersebut, meliputi: pertama, fenomenologis digunakan untuk menggali pengalaman legitimasi masing-masing elit enam agama dan esensi makna nilai-nilai agama yang diyakini (meaningful choice) elit enam agama dalam membangun persaudaraan lintas iman. Kedua, interaksionisme simbolik digunakan sebagai metode analisis dalam memahami dinamika perubahan legitimasi dan identitas masing-masing elit agama secara individu maupun kelembagaan (Denison, 2011: 10).

Penggunaan penelitian kualitatif ini menjawab asumsi dari: (1) pengetahuan mengenai persaudaraan lintas iman masih bersifat semu di kalangan elit enam agama. (2) Penemuan konsep persaudaraan lintas iman dipahami sebagai interaksi antara peneliti dan yang diteliti. (3) Interpretasi dari pengalaman hidup elit enam agama yang menjalani persaudaraan lintas iman adalah kunci untuk memahami makna persaudaraan lintas iman.

Lokasi penelitian ini adalah kota Palangka Raya. Kota ini memiliki karakteristik kaya keberagamaan secara kultural maupun religius. Komunitas lintas iman banyak terbentuk di kota ini seperti: Forum Kerukunan Umat Beragama (FKUB), Perempuan Antar Umat Beragama (PAUB), Gerakan Muda Umat Beragama (Gema UB), Forum
Doa Bersama (FDB). Organisasi sosial keagamaan seperti NU dan Muhammadiyah juga aktif menggelar kegiatan bertemakan kerukunan hidup antar umat beragama. Sementara pengumpulan data dilakukan dengan wawancara individual dengan elit agama terpilih sebagai informan kunci meliputi: H. Abdul Wahid, penasihat Nahdlatul Ulama Cabang Palangka Raya dari elit agama Islam; Pastor, Keuskupan Palangka Raya dari elit agama Katolik yaitu Wilhelmus Noya; Pendeta Drs. PL Sinaga, ketua Parisada Hindu Dharma Indonesia Cabang Palangka Raya dari elit agama Hindu; Alber Kumala, sekretaris Walubi Cabang Palangka Raya dari elit agama Budha; dan Bunsu Anton Triyono, seorang rohaniawan Konghucu. Sedangkan teknik observasi partisipasi, focus group discussion, dokumentasi dijadikan sebagai data sekunder dalam penelitian ini.

Teknik analisis data dalam penelitian ini merujuk pada tahapan analisis interaksionisme simbolik yang dikembangkan Mead yang meliputi (1) Impuls. (2) Persepsi, (3) Manipulasi, (4) Konsumasi (Mead, 1972: 75).

\section{PEMBAHASAN}

Pada tahap pertama yaitu impuls, peneliti menganalisis dorongan hati yang meliputi stimulasi/ rangsangan spontan yang berhubungan dengan indera dan reaksi elit enam agama terhadap makna legitimasi dan identitas. Dalam proses tersebut, peneliti juga mengkaitkan data mengenai makna legitimasi dan identitas yang dipahami elit enam agama dengan situasi terkini, pengalaman masa lalu dan aksi yang dilakukan di masa depan. Pada tahap kedua yaitu persepsi, peneliti melakukan penyelidikan makna reaksi konsep persaudaraan lintas iman yang dibangun dari pemahaman legitimasi dan identitas yang dipahami elit enam agama. Dari proses ini, elit enam agama akan melakukan refleksi diri dari stimuli yang dilihat dan dipahami (pendengaran, senyuman, rasa dan sebagainya). Selanjutnya, elit enam agama akan secara aktif membuat keputusan mengenai persaudaraan lintas iman yang dikonstruksi dari makna legitimasi dan identitas (Mead, 1972: 42- 87).

Pada tahap ketiga yaitu manipulasi, peneliti memberi jeda waktu berpikir kepada elit enam agama untuk memikirkan berbagai alternatif persaudaraan lintas iman yang bisa dikonstruksi. Hal ini dilakukan agar elit enam agama tidak tergesagesa/spontanitas mengkonstruksi persaudaraan lintas iman. Pada tahap ini, peneliti berupaya 
merumuskan model persaudaraan lintas iman yang lebih matang, sistematis dan konstektual melalui pemberian waktu jeda berpikir kepada para elit enam agama. Pada tahap terakhir yaitu konsumasi, peneliti menganalisis tindakan yang memuaskan dorongan hati yang sebenarnya dari elit enam agama berkenaan dengan konstruksi persaudaraan lintas iman yang telah dirumuskan. Pada tahap akhir ini, apabila tindakan masing-masiing elit enam agama dalam mengkonstruksi persaudaraan lintas iman ditanggapi sama, maka menjadi simbol signifikan. Nilai global dari persaudaraan lintas iman merupakan simbol signifikan dari analisis interaksionisme simbolik relasi legitimasi dan identitas elit agama (Mead, 1972: 88-125).

Perpaduan teori legitimasi, interaksionis simbolik, dan identitas dalam penelitian ini menawarkan lima wawasan mendalam dari persaudaraan lintas iman yang meliputi: pertama, posisi setiap elit agama dalam membangun relasi keberagamaan. Kedua, konstruksi sosial elit agama yang secara konstan berbagi nilai keberagamaan di setiap interaksi. Ketiga, konteks struktur sosial yang terungkap dalam setiap refleksi dan interaksi antar elit agama. Keempat setiap elit agama terpola menjadi berbagai identitas. Gambaran dari berbagai pola identitas (multiple identities) merefleksikan berbagai posisi dan peran yang dihayati elit agama dalam membangun persaudaraan lintas iman pada setiap interaksi. Kelima, konsekuensi sosial yang didapat dari relasi dan interaksi elit agama dalam persaudaraan lintas iman (Simon, 2004: 25).

Pengecekan keabsahan data dilakukan dengan teknik triangulasi dan peer debriefing (berdiskusi dengan teman sejawat) untuk memberikan masukan bahkan kritikan, yaitu: Sugeng Riyadi, MA dan Pendeta Yoto selaku cendekiawan yang aktif menggalang dialog lintas agama di kota Palangka Raya. Sedangkan pertimbangan etis dalam penelitian ini dilaksanakan dengan masuk ke daerah penelitian setelah mendapat izin dari Kantor Kementerian Agama Kota Palangka Raya maupun organisasi sosial masyarakat yang menaungi elit agama. Secara informal peneliti mendatangi tokoh-tokoh agama kota Palangka Raya terutama yang terkait di bidang keberagamaan. Peneliti juga menerapkan prinsipprinsip dalam meneliti manusia seperti menjaga konfidensialitas dan hak subyek untuk keluar dari penelitian ini apabila tidak sesuai dengan maksud dari penelitian ini.

Tugas FKUB sebagimana tercantum dalam pasal 9 ayat (a) adalah melakukan dialog dengan pemuka agama dan tokoh masyarakat. Sampai saat ini sejak FKUB Provinsi Kalimantan Tengah terbentuk pada tahun 2006 dan dilantik pada tanggal 23 Oktober 2007 secara formal sebagai sebuah kegiatan yang diprakarsai oleh FKUB untuk melakukan dialog dengan pemuka agama dan tokoh masyarakat belum pernah dilakukan, yang terjadi adalah dialog-dialog non formal atau dialog pada kesempatan dimana anggota FKUB. Namun demikian dialog-dialog sering dilakukan oleh anggota FKUB masing-masing dari majelis agama terhadap intern umatnya.

Dari hasil wawancara terhadap masingmasing perwakilan majelis agama yang tergabung dalam wadah FKUB, selama ini secara formal FKUB belum pernah menampung aspirasi ormas keagamaan maupun masyarakat. Namun demikian, ada aspirasi-aspirasi yang dikemukan oleh para perwakilan majelis yang duduk sebagai anggota FKUB, misalnya aspirasi yang dikemukakan oleh perwakilan agama Konghucu agar siswa yang beragama Konghucu dapat diberikan pelajaran agama Konghucu, yang diajarkan oleh seorang guru yang beragama Konghucu. Dari aspirasi-aspirasi yang dikemukakan di atas telah disampaikan kepada pemerintah daerah melalui mekanisme yang ada namun sampai saat penelitian ini dilakukan belum dapat terpenuhi

Untuk FKUB Provinsi Kalimantan Tengah yang telah dilakukan sosialisasi baru terbatas pada sosialisasi PBM. Hal ini juga menurut penuturan beberapa anggota FKUB belum pernah secara khusus kegiatan dilakukan oleh FKUB, yang ada adalah kegiatan-kegiatan selipan yang dilakukan pada kesempatan-kesempatan jika anggota FKUB diundang oleh FKUB kabupaten/kota pada saat pelantikan mereka.

Untuk pemberdayaan ormas dan masyarakat sebagaimana tugastugas yang lain secara formal FKUB belum melaksanakan tugas-tugasnya secara maksimal mengacu pada kegiatan sendiri namun demikian secara terpisah anggota FKUB dari masing-masing majelis agama telah melakukan pemberdayaan tersebut seperti dari Katolik terhadap kaum mudanya, OMK (Orang Muda Katolik), Pengurus Dewan Pastoral Paroki Umat, materinya tentang pembinaan umat, khusus tentang toleransi umat beragama, kepemimpinan dan organisasi (Wawancara dengan Wilhelmus perwakilan dari Katolik).

Penduduk Provinsi Kalimantan Tengah dari segi pemeluk agama pada tahun 2014, mayoritas Islam sebanyak 1.623 .643 jiwa (78\%), Kristen 346.559 jiwa (17\%), Katolik 76.419 jiwa (0.4\%), 
Hindu 26.128 jiwa (0.1\%), Buddha 1.441 jiwa (0.01\%) dan lainnya 1.401 jiwa (0.01\%) (BPS Provinsi Kalteng, 2011:160). Rumah ibadat yang tercatat pada tahun 2010 terdiri dari Islam 1.620 masjid (49\%), Kristen 1.406 gereja (43\%), Katolik 161 gereja induk $(0.05 \%)$, Hindu 78 pura $(0.02 \%)$, Buddha 14 vihara (0.004\%). Jumlah tersebut belum termasuk 1.960 langgar dan 498 mushalla, 169 balai jemaat Kristen dan 428 pastori, 74 gereja pembantu Katolik, 45 sanggah dan 427 balai hindi serta sebuah Cetia (BPS Provinsi Kalteng, 2014:160-161).

Sedangkan rumah ibadat di Kota Palangka Raya: Islam 112 masjid (54\%), Kristen 88 gereja (43\%), Katolik 1 gereja induk $(0.005 \%)$, Hindu 3 pura $(0.01 \%)$, Buddha 2 vihara $(0.01 \%)$. Jumlah tersebut belum termasuk 118 langgar/mushalla, 8 pastori, 4 gereja pembantu dan 15 balai Katolik, (FKUB Kabupaten Palangka Raya, 2014:13).

Secara umum keadaan umat beragama di Kota Palangka Raya kondusif rukun (Achmad Diran, 5 Juni 2014, Djawahir Tanthowi, 7 Juni 2014), Dalam sebuah keluarga Dayak adalah biasa menganut agama yang berbeda. Tradisi silahturahim sangat kental dengan saling kunjung mengunjungi antar mereka yang berbeda agama seperti pada saat terjadi perkawinan, perayaan hari-hari besar keagamaan, saling kerjasama dalam kepanitiaan, seperti panitia Musabaqoh Tilawatil Qur'an, Pesparawi Kristen, Atsana Dharma Gita Hindu, Pesta Tandak Intan Kaharingan dan festival pembacaan kitab suci Dharmapada, serta adanya pembinaan kehidupan beragama oleh pemerintah. Selain itu juga berkembang kearifan lokal seperti "open house" atau menerima tamu pada hari-hari besar keagamaan dan penggunaan pengeras suara di rumah ibadat yang peduli lingkungan (FKUB Kota Palangka Raya, 2010:5-7).

Di kalangan umat beragama Kalimantan Tengah, tumbuh dan berkembang organisasi keagamaan. Di antaranya yang tercatat pada Kantor Kementerian Agama tahun 2010 mencapai 55 buah dan yang tercatat di kantor Kementerian Agama Kota Palangka Raya sebanyak 38 buah. Di antaranya organisasi Islam yaitu: MUI, GP Anshor, Fatayat, Muslimat NU, IPNU, FKDMI, Pemuda Muhammadiyah, IMM, IRM, Nasyiatul Aisyiah, PMII, HMI, BPRMI, Pemuda Muslimin Indonesia (PMI), KAMMI, MMI, Al Hidayah, Pemuda Islam, Hizbut Tahrir, Lembaga Dakwah Islam Indonesia (LDII), LPTQ, Majelis dakwah Islamiyah (MDI), Toriqoh Mu'tabaroh, dan Ikatan Cendikiawan Muslim Indonesia (ICMI). Di kalangan Kristen terdapat Persekutuan Gereja-Gereja di Indonesia
(PGI), DPI, PII dan Eka Shinta. Di kalangan Katolik tercatat ada PMKRI.

Kota Palangka Raya saat ini dalam kondisi yang kondusif. Kondisi ini tidak terlepas dari kekuatan potensi rukun yang dimiliki, salah satunya berdasarkan kearifan lokal. Kearifan lokal itu terdapat pada Rumah Betang, yakni rumah panjang yang dihuni berbagai anggota keluarga yang mungkin juga berbeda agama, yang dilandasi cinta kasih, persaudaraan dan kerukunan.

Jika setiap keluarga memiliki Rumah Betang, maka keseluruhan masyarakat akan memiliki ikatan kerukunan yang kuat. Sebab sebagai totalitas sosial, masyarakat telah dibentuk oleh sub-keluarga yang telah mampu mengamalkan kerukunan beragama dalam kehidupan kesehariannya, dan ini berkat mediasi Rumah Betang (Kearifan Lokal Daerah, Puslitbang Kehidupan Keagamaan, Tahun 2009).

\section{PENUTUP}

Proses interaksionisme simbolik legitimasi elit enam agama dalam mengkonstruksi persaudaraan lintas iman di kota Palangka Raya cukup baik walaupun seringkali tersendat-sendat karena kesibukan para pengurus dengan kegiatan masingmasing dan masih perlu penataan

Model interaksionisme simbolik relasi legitimasi dan identitas elit enam agama dalam mengkonstruksi persaudaraan lintas iman di kota Palangka Raya dengan melihat persaudaraan' huma betang sehingga tetap terlihat rasa persaudaraan sekalipun menjalani agama (iman) yang berbeda

\section{UCAPAN TERIMA KASIH}

Terima kasih penulis ucapkan kepada tokohtokoh agama Kota Palangka Raya dan seluruh informan yang tidak dapat disebutkan atas berbagai bantuan dan informasi yang diberikan terkait penelitian. Kepada tim redaksi jurnal Al-Qalam atas termuatnya tulisan ini.

\section{DAFTAR PUSTAKA}

Abu-Nimer, Mohammad. A Framework for Nonviolence and Peacebuilding in Islam, Journal of Law and Religion, Vol. 15, No. 1/2 (2000 - 2001)

Beetham, David, 1991. The Legitimation of Power. New York: Palgrave.

Coleman, Katharina P. 2007. International Organisations and Peace Enforcement The Politics of International Legitimacy. Cambridge: Cambridge University Press.

Denison, Barbara Jones Denison (Ed). 2011. History, 
Time, Meaning, and Memory Ideas for the Sociology of Religion. Leiden: Brill.

Denzin, Norman K \& Yvonna S. Lincoln. 2009. Handbook of Qualitative Research. Terj. Dariyatno, dkk. Yogyakarta: Pustaka Pelajar.

Eldering, Lotty. 1996. Multiculturalism and Multicultural Education in an International Perspective, Anthropology and Education Quarterly, Vol. 27, No. 3. American Anthropological Association.

Hand, Michael. 2006. Is Religious Education Possible? A Philosophical Investigation. New York \& London: Continuum International Publishing Group.

Hwang, Julie Chernov. 2011. Umat Bergerak Mobilisasi Damai Kaum Islamis Di Indonesia, Malaysia, Dan Turki. Terj.Samsuddin Berlian. Jakarta: Freedom Institute.

Mead, George H. 1972. Mind, Self, and Society From The Standpoint Of A Social Behaviorist. Chicago \& London: The University of Chicago Press.
Meer, Nasar. 2010. Citizenship, Identity and the Politics of Multiculturalism The Rise of Muslim Consciousness. New York: Palgrave Macmillan.

Moore, Christopher W dan Peter J. Woodrow. 2010. Handbook of Global and Multicultural Negotiation. San Fransisco: Jossey-Bass.

Peek, Lori. 2005. Becoming Muslim. The Development of a Religious Sociology of Religion, Vol. 66, No. 3. Oxford: Oxford University.

Rehfeld, Andrew. 2005. The Concept of Constituency Political Representation, Democratic Legitimacy, and Institutional Design. Cambridge: Cambridge university press.

Simon, Bernd. 2004. Identity in Modern Society: a Social Psychological Perspective. Victoria: Blackwell Publishing.

Tyler, Tom R. 2006. Psychological Perspectives on Legitimacy and Legitimation. New York: Annual Review Psychology. 